\title{
Disease Management Practices among Rabbit Farmers in Enugu State Nigeria
} https://dx.doi.org/10.4314/jae.v22i3.13

\section{Chah, Jane Mbolle}

Department of Agricultural Extension

University of Nigeria, Nsukka, Enugu State, Nigeria

Email: jane.chah@unn.edu.ng

Phone: 08032420600

\section{Attamah, Clement Okechukwu}

Department of Agricultural Extension

University of Nigeria, Nsukka, Enugu State, Nigeria

Email: clement.attamah@unn.edu.ng

Phone:07035397081

\section{Nnodim, Maduabuchi Emmanuel}

Department of Agricultural Extension

University of Nigeria, Nsukka, Enugu State, Nigeria

Email: maduabuchi.nnodim.169902@unn.edu.ng

\begin{abstract}
The study assessed disease management practices among rabbit farmers in Enugu State, Nigeria. Structured interview schedule was used for data collection from 67 respondents in the state, using snow ball sampling technique. Descriptive statistics was used in data analyses. Findings reveal that the majority of the rabbit farmers were single male, with mean age of 20years and 1.2years of experience in rabbit farming. The majority (73.1\%) of the respondents had a stock size of 1-10 rabbits with mean flock size of 2 rabbits. New Zealand white was the most possessed and preferred breed. Greater proportion (55.2\%) of the respondents obtained their breeding stock from other farmers, with health status being the most important factor considered when selecting breeding stock. The study established that $68.9 \%$ of the respondents used modern drugs in treatment of diseases and hence, recommended that extension agents should reach out to rabbit farmers with relevant information that could boost their production and in turn increase their living standard.
\end{abstract}

Keywords: Disease management, Rabbit production, Enugu State

\section{Introduction}

The steady growth of Nigeria population calls for an effective and efficient means of meeting the protein demands of her population (Mailafia, Onakpa, and Owoleke, 2010). Shortage of protein, particularly those of animal origin is prevalent in most parts of the country (Abdulraheem, Olasore and Oni, 2016). In order to ensure adequate supply of protein to the rapidly growing population of Nigeria, the output of 
Creative commons User License: CC BY-NC-ND

Abstracted by: EBSCOhost, Electronic Journals Service (EJS), Google Scholar, Journal Seek, Scientific Commons,

Food and Agricultural Organization (FAO), CABI and Scopus
Journal of Agricultural Extension

Vol. 22 (3) October, 2018

ISSN(e): 24086851; ISSN(Print); 1119944X

http://journal.aesonnigeria.org

http://www.aiol.info/index.phpliae

Email: editorinchief@aesonnigeria.org

animal products has to be increased especially by short cycle animals such as rabbits and poultry (Ogbonna, 2015). Unfortunately, poultry require food sources which are in direct competition with man, while rabbits can be produced from the enormous forages and feed materials that freely abound in the tropics.

Rabbit possesses a number of features that might be of advantage in the smallholder subsistence type of integrated farming that is common in Enugu State, e.g. high growth rate, high efficiency in converting forage to meat, short gestation period, and high prolificacy, relatively low cost of production, high nutritional quality of rabbit meat which includes low fat, and sodium levels. It also has a high protein level of about $20.8 \%$ and its consumption is bereft of cultural and religious biases (Mailafia, Onakpa, and Owoleke, 2010).

However, low productivity of rabbit has limited their potential to improve the living standard of farmers in terms of income earning, animal protein requirement and significant contribution to rural development. This low productivity could be linked to lack of technical know-how in rabbit production, market-related problems (Ogbonna, 2015), disease infestation among others. Common rabbit diseases are: diarrhoea, coccidiosis, conjunctivitis, ear canker, and pneumonia (Commercial Livestock Production Guide Series, nd). Disease infestation has been established as an enemy to productivity. According to Grund (2016) the illness and loss of life from diseases decreases productivity and hurts a country's economy. Hence, it is better to prevent an outbreak of disease than to try to get rid of it, once it has started. The best protection against diseases in general is to follow a careful sanitation programme. Maintaining sanitary conditions in hutches (pens) is a major preventive measure for controlling diseases in the rabbitry.

Given the fact that management of rabbit is the major determinant of productivity in rabbit, there is therefore need for proper management to increase the production of healthy, strong and safe rabbits. To achieve this, there is need to consider what farmers are doing with regards to disease management in rabbit production in Enugu State.

The relevant questions that guided this study were; What are the preferred breeds by the farmers? What are the sources of breeding stock? What were the disease management practices? What are the sources of information on rabbit disease/ treatment? What are the constraints to rabbit disease management?

\section{Methodology}

The study was conducted in Enugu State. The climate of the state can generally be described as tropical with two clear identifiable seasons, the wet and dry seasons. Rabbit keepers in the state constituted the population for the study. A snow ball sampling technique was used (due to few number of rabbit farmers) to identify 67 rabbit keepers for the study.

Structured interview schedule was used for data collection. The instrument was validated by four academic staff of the Department of Agricultural Extension, University of Nigeria Nsukka and pre-tested before use. Farmers were asked to indicate the breed of rabbit they have, from a list, such as New Zealand white, 
Creative commons User License: CC BY-NC-ND

Abstracted by: EBSCOhost, Electronic Journals Service (EJS), Google Scholar, Journal Seek, Scientific Commons,

Food and Agricultural Organization (FAO), CABI and Scopus
Journal of Agricultural Extension

Vol. 22 (3) October, 2018

ISSN(e): 24086851; ISSN(Print); 1119944X

http://journal.aesonnigeria.org

http://www.ajol.info/index.php/iae

Email: editorinchief@aesonnigeria.org

Californian white, Chinchilla, Dutch, among others. From a list of options, such as own stock, other rabbit farmers, government farms, market, research institutions, farmers were asked to indicate the source(s) of their breeding stock. They were asked to tick from a list of options, what factors they considered when selecting breeding stock (breed type, health status, ancestry, growth rate, and mothering ability). Farmers were asked to list the common diseases in their rabbit farms and season of occurrence. Farmers were also asked to indicate their action when there is a disease problem among their rabbits (personal treatment, calling of an animal health professional, culling the infected animals, among others), and the method of disease treatment they use, whether orthodox/modern drugs, indigenous technical knowledge, or both. Farmers were asked to indicate their sources of information (fellow farmers, media (radio, television, print), veterinarians, extension officers, and Internet) on the appropriate drugs to administer for disease treatment. They were also asked if veterinary services, drugs for rabbit disease treatment, and information to farmers on rabbit disease were readily available. Finally, they were asked if the cost of drugs for rabbit disease treatment and/or veterinary services was too high. Lists of possible constraints were also outlined as follows: unavailability of veterinary doctors, unavailability of vaccines/drugs, strange and unfamiliar disease symptoms, lack of training on disease management, poor extension contact among others. Respondents were asked to indicate the level of perceived seriousness of the disease management constraints on a 3-point Likert-type scale of; to a great extent $=3$, to a little extent $=2$, to no extent $=1$. These values were added together $(3+2+1)$ to obtain the sum six $(6)$ which when divided by three (3) gave a mean of 2 . Variables with mean score of 2 and above were considered as possible constraining variables while those below 2 were considered as not a constraining variable to rabbit disease management. The data generated was subjected to descriptive statistics.

\section{Results and Discussions}

\section{Socioeconomic Characteristics}

Table 1 shows that the majority (94\%) of the rabbit producers were male who were mainly single (91\%) with an average age of 20.37 years and had spent an average of 1.19 years in rabbit production in Enugu State. Seventy-three percent of the respondents had stock size of 1-10 and mean stock size of 2 rabbits. The majority (67\%) generated an annual income of less than $\$ 21,000$ but $\$ 29,397.39$ on the average. This shows that the farmers were majorly small-scale farmers who has the capacity to increase their scale of production owning to their energetic nature (youthfulness). 
Table 1: Socio-economic characteristics of the respondents

\begin{tabular}{lll}
\hline Variables & $\begin{array}{l}\text { Percentage } \\
(\mathbf{n}=67)\end{array}$ & Mean $(\bar{x})$ \\
\hline Sex & 94 & \\
Male & 6 & \\
Female & \\
Age (years) & 70.1 \\
$11-20$ & 22.5 & \\
$21-30$ & 3 & \\
$31-40$ & 1.5 & \\
$41-50$ & 1.5 & \\
$51-60$ & 3 & \\
61 and above & & \\
Marital status & 91 & \\
Single & 6 & \\
Married & 3 & \\
Widowed & & \\
Years of experience in rabbit farming & \\
$1-6$ & 88.1 & \\
$7-12$ & 7.5 & \\
$13-18$ & 1.5 & \\
19 and above & 3.0 & \\
Stock size & & \\
$1-10$ & 73.1 & \\
$11-20$ & 10.4 & \\
$21-30$ & 9.0 & \\
31 and above & 7.5 & \\
Annual income from rabbit (n=27) & & \\
Less than 21,000 & 66.7 & \\
$21000-40999$ & 14.8 & \\
$41000-60999$ & 7.4 & \\
61000 and above & 11 & \\
& & \\
& &
\end{tabular}

\section{Rabbit Breeds Possessed by Farmers}

Entries in Table 2 show that the majority (58.2\%) of the respondents possessed New Zealand white breed of rabbit. Californian white accounted for $35.8 \%$, Chinchilla was $31.3 \%$, and Dutch breed was $22.5 \%$. About $16 \%$ had Flemish giant, $15 \%$ had cross breeds, $6 \%$ had French lopped, 1.5\% had Angora and 1.5\% had Kenya white. The three most preferred breeds by the respondents were, New Zealand white, Californian white and Chinchilla. This could be due to the prolific nature of New Zealand white. This agrees with the findings of Baruwa (2014) in Osun State, who reported that the two most popular breeds reared are New Zealand and the Californian white breeds. 
Creative commons User License: CC BY-NC-ND

Abstracted by: EBSCOhost, Electronic Journals Service (EJS),

Google Scholar, Journal Seek, Scientific Commons,

Food and Agricultural Organization (FAO), CABI and Scopus
Journal of Agricultural Extension

Vol. 22 (3) October, 2018

ISSN(e): 24086851; ISSN(Print); 1119944X

http://journal.aesonnigeria.org

http://www.ajol.info/index.php/iae

Email: editorinchief@aesonnigeria.org

Table 2: Breeds of rabbit possessed by farmers

\begin{tabular}{ll}
\hline Breeds $^{*}$ & Percentage $\mathbf{( n = 6 7 )}$ \\
\hline New Zealand white & 58.2 \\
Californian white & 35.8 \\
Chinchilla & 31.3 \\
Dutch & 22.5 \\
Flemish giant & 16.4 \\
Cross breed & 15 \\
French lopped & 6 \\
Angora & 1.5 \\
Kenya white & 1.5 \\
*Multiple choice &
\end{tabular}

\section{Source of Breeding Stock}

The data in Table 3 reveals that farmers got most (55.2\%) of their breeding stock from other farmers, followed by their own stock (37.3\%), market $(35.8 \%)$, and $4.5 \%$ from research institutions. This could be linked to the fact that rabbit production is new in the area as can be seen in the average years of experience of the farmers which is less than two, and the average stock size of two rabbits. Naturally, farmers are known to always consult others that are in a business before them for information and guidance. This is in line with innovation diffusion theory.

\section{Factors Considered during Selection of Breeding Stock}

The data on Table 3 show that the most considered factor in the selection of breeding stock is health status of the rabbit (92.5\%). Other factors included: breed type $(49.3 \%)$, growth rate $(44.8 \%)$, and mothering ability $(32.8 \%)$. This implies that farmers placed high premium on possessing a disease-free farm, as diseases are known to affect productivity and can mar farmers' efforts.

Table 3: Sources of breeding stock

\begin{tabular}{ll}
\hline Source of breeding stock* & $\begin{array}{l}\text { Percentage } \\
(\mathbf{n}=67)\end{array}$ \\
\hline Own stock & 37.3 \\
Other farmers & 55.2 \\
Market & 35.8 \\
Research institution & 4.5 \\
Factors considered when & selecting breeding \\
stock $^{*}$ & \\
Breed type & \\
Health status & 49.3 \\
Ancestry & 92.5 \\
Growth rate & 7.5 \\
Mothering ability & 44.8 \\
Litter size & 32.8 \\
\hline
\end{tabular}

${ }^{*}$ Multiple choice

Source: Field work, 2015 
Creative commons User License: CC BY-NC-ND

Abstracted by: EBSCOhost, Electronic Journals Service (EJS), Google Scholar, Journal Seek, Scientific Commons,

Food and Agricultural Organization (FAO), CABI and Scopus
Journal of Agricultural Extension

Vol. 22 (3) October, 2018

ISSN(e): 24086851; ISSN(Print); 1119944X

http://journal.aesonnigeria.org

http://www.ajol.info/index.php/iae

Email: editorinchief@aesonnigeria.org

\section{Rabbit Diseases Management}

About $82 \%$ of the respondents indicated that rabbit disease is not a problem on their farm, while $17.9 \%$ indicated that it is a problem. This could be associated with the fact that farmers placed high importance in selecting healthy rabbit as breeding stock. It might also be because most of the farmers are still new in the business to have any account of disease infestation, and again, the farmers possess few rabbit stocks which could reduce the chances of disease incidence. It also normal with humans to pay close attention to new business, and as such will readily detect any disease symptom.

Among the few farmers that had experienced disease problem in their farm, mange was recorded as the most $(75 \%)$ common disease. Others included ear canker $(8.3 \%)$, sniffles $(8.3 \%)$ and diarrhea $(8.3 \%)$. This is in accordance with the report of Merck (2010) that mange is a common problem with rabbits and is a skin parasitic condition caused by Sarcoptes scabiei, and as a result of pruritis, it leads to scab formation and alopecia. Mange causes rabbits to lose appetite, body condition and stunts the growth rate.

Table 4 shows that the majority $(76.1 \%)$ of the farmers treats their rabbits themselves when diseased. About $18 \%$ called the attention of veterinary doctors, while $6 \%$ culled infested animals. The resulting to self-medication could be a way of cutting cost on the part of the farmers but could be highly detrimental in livestock business. It could also be possible to reduce disease infestation to barest minimum when farmers learn the act of employing the services of veterinary doctors. It has been established that the major cause of death even in humans is self-medication. The push for selfmedication by the majority could also be associated with their stock size; which is small; two on the average. The small body size of rabbit could also propel farmers into self-medication; as farmers can easily forgo rabbit.

The majority $(68.9 \%)$ of the farmers used modern drugs in the treatment of diseases. About $28 \%$ used indigenous method, while $3.5 \%$ combined both methods. This might be that there is access to affordable rabbit medication. The average stock size of two could also be a motivating factor for the usage of modern drugs, as the cost of treatment may be cheap when compared to treating large stock size.

\section{Season of Rabbit Disease Occurrence}

Table 4 also shows that only about $33.3 \%$ of the respondents established that rabbit disease occurs with season. Farming experience of less than two years may not have given the farmers ample time or opportunity to observe the peak period of rabbit diseases.

\section{Source of Information on Appropriate Drugs for Diseases Treatment}

The majority $(55.3 \%)$ of the farmers sourced information on appropriate drugs for rabbit treatment from fellow farmers. Information from veterinarians accounted for $36.8 \%$, Internet was $5.3 \%$, while self or personal knowledge accounted for $2.6 \%$. This could be that the farmers have more trust and confidence on fellow farmers especially those that are into the enterprise before them, as they could be speaking from experience. This is in accordance with the report of Mbutu (2013) that more rabbit 
Creative commons User License: CC BY-NC-ND

Abstracted by: EBSCOhost, Electronic Journals Service (EJS), Google Scholar, Journal Seek, Scientific Commons,

Food and Agricultural Organization (FAO), CABI and Scopus
Journal of Agricultural Extension

Vol. 22 (3) October, 2018

ISSN(e): 24086851; ISSN(Print); 1119944X

http://journal.aesonnigeria.org

http://www.ajol.info/index.php/iae

Email: editorinchief@aesonnigeria.org

farmers were influenced by their neighbors as they searched for information on rabbit farming from them as well as from livestock officers.

\section{Availability of Veterinary Services}

Table 4 shows that $63.1 \%$ of the farmers indicated the availability of veterinary services. This may be the reason why the farmers experienced low disease incidence in their rabbit farm, as they may be abreast with the right vaccination processes even without direct consultation. The availability of resource persons in an environment generally tend to reduce what people in the area can suffer as knowledge on what to do tends to be high.

\section{Cost of Drugs and Veterinary Services}

Results in Table 4 also show that the majority (70.3\%) of the farmers indicated that the cost of drugs and/ veterinary services for rabbit treatment was not high. This could be associated to the high premium on selection of healthy breeding stock and low incidence of disease infestation among farmers. The low cost in drugs and veterinary services could also be associated to low demand of veterinary services among farmers, as demands generally tends to affect price.

Table 4: Rabbit diseases management

\begin{tabular}{|c|c|}
\hline Variables & Percentage $(n=67)$ \\
\hline \multicolumn{2}{|l|}{ Incidence of rabbit diseases } \\
\hline Yes & 17.9 \\
\hline No & 82.1 \\
\hline \multicolumn{2}{|l|}{ Most common diseases ${ }^{*}$} \\
\hline Ear canker & 8.3 \\
\hline Sniffles & 8.3 \\
\hline Mange & 75.1 \\
\hline Diarrhoea & 8.3 \\
\hline \multicolumn{2}{|l|}{ Reaction to rabbit disease problem* } \\
\hline Personal treatment of rabbit diseases & 76.1 \\
\hline Calling a veterinarian & 17.9 \\
\hline Culling the infected animal & 6 \\
\hline \multicolumn{2}{|l|}{ Method of disease treatment/control ${ }^{*}$} \\
\hline Modern drugs & 68.9 \\
\hline Indigenous knowledge & 27.6 \\
\hline Both & 3.5 \\
\hline \multicolumn{2}{|l|}{ Rabbit disease occurrence with season } \\
\hline Yes & 33.3 \\
\hline No & 66.7 \\
\hline \multicolumn{2}{|c|}{ Sources of information on appropriate drugs for rabbit diseases treatment } \\
\hline Fellow farmers & 55.3 \\
\hline Media & 0 \\
\hline Veterinarians & 36.8 \\
\hline Extension officers & 0 \\
\hline Internet & 5.3 \\
\hline Personal knowledge/experience & 2.6 \\
\hline \multicolumn{2}{|l|}{ Availability of veterinary services } \\
\hline Yes & 63.1 \\
\hline No & 36.9 \\
\hline \multicolumn{2}{|l|}{ Cost of drugs and veterinary services } \\
\hline High & 29.7 \\
\hline Not high & 70.3 \\
\hline
\end{tabular}

Source: Field work, 2015

*Multiple choice 
Creative commons User License: CC BY-NC-ND

Abstracted by: EBSCOhost, Electronic Journals Service (EJS), Google Scholar, Journal Seek, Scientific Commons,

Food and Agricultural Organization (FAO), CABI and Scopus
Journal of Agricultural Extension

Vol. 22 (3) October, 2018

ISSN(e): 24086851; ISSN(Print); 1119944X

http://journal.aesonnigeria.org

http://www.ajol.info/index.php/iae

Email: editorinchief@aesonnigeria.org

\section{Constraints to Rabbit Disease Management}

Table 5 shows that the majority (62.7\%) of the respondents indicated that they do not have any constraint on rabbit disease management, while $37.3 \%$ indicated that they had constraints on disease management. The fact that the majority showed lack of constraints on disease management could be connected to the precautionary or preventive measures adopted by the farmers, such as placing more importance on health status while selecting breeding stocks. This could as well be associated with the fact that most farmers are new in the business, as constraints tend to be more obvious over time. Hence, the chances of having more constrained farmers as time goes on, is possible. With $37.3 \%$ constrained farmers in less than two years of production, is a pointer that there could be more as time progresses.

Table 5: Perceived constraints to rabbit disease management

\begin{tabular}{|c|c|c|c|}
\hline $\begin{array}{l}\text { Constraint } \\
\text { management }\end{array}$ & to & disease & Percentage $(n=67)$ \\
\hline $\begin{array}{l}\text { Yes } \\
\text { No }\end{array}$ & & & $\begin{array}{l}37.3 \\
62.7\end{array}$ \\
\hline
\end{tabular}

Source: Field work, 2015

Perceived constraining variables on rabbit disease management as can be seen on Table 6 included; poor extension contacts $(\bar{x}=2.20)$, lack of training on disease management

$(\bar{x}=2.08)$, and strange and unfamiliar symptoms $(\bar{x}=2.00)$. Extension is meant to guide farmers on how best to prevent or control diseases on the farm. They serve as bridge between subject matter specialists and farmers. Hence, lack of touch with extension could send danger signal to farmers. Training helps to empower farmers to withstand eventualities while absence of it could be perceived as disadvantageous. Strange and unfamiliar symptoms could pose a challenge to disease management, as farmers who may not want to involve the service of veterinary doctors could be stranded.

Table 6: Perceived constraints to rabbit disease management

\begin{tabular}{lll}
\hline Constraining variables & Mean & STD \\
\hline Unavailability of veterinary doctors & 1.70 & 0.70 \\
Unavailability of vaccines & 1.68 & 0.78 \\
Strange and unfamiliar symptoms & $2.00^{*}$ & 0.51 \\
Lack of training on disease & $2.08^{*}$ & 0.40 \\
management & & 0.76 \\
Poor extension contacts & $2.20^{*}$ &
\end{tabular}

Source: Field work, 2015 


\section{Conclusion and Recommendations}

The study concluded that farmers placed high premium on selecting disease-free rabbits as breeding stock. It also pointed out that farmers treat their animals themselves using modern drugs, majorly. It therefore recommended that farmers should minimize the usage of personal experiences in diseases management but should make effort to engage the services of veterinary doctors in ensuring healthy farm, since they are available. Extension agents should reach out to rabbit farmers with relevant information that could boost their production and in turn increase their living standard.

\section{References}

Abdulraheem, M.A., Olasore, A.O. \& Oni, O.O. (2016). Assessment of animal protein consumption and food security among rural households in Kwara State, Nigeria. American Journal of Business and Society, 1(4), 233-245. http://www. aiscience.org/journal/aibs

Baruwa, I. O. (2014). Profitability and constraints to rabbit production under tropical conditions in Nigeria. Journal of Livestock Science, 5: 83-88. (ISSN online 2277-6214)

Commercial Livestock Production Guide Series (n.d). Rabbity in Nigeria. International Institute for Tropical Agriculture (IITA).

Grund, A. S. (2016). Animal Kingdom: Effects of Animal Diseases. Orbis Biosciences. http:/www.orbisbio.com/BlogRetrieve.aspx?

Mailafia, S., Onakpa, M.M. and Owoleke, O.E. (2010). Problems and prospects of rabbit production in Nigeria - A review. Bayero Journal of Pure and Applied Science, 3 (2): 20-25.

Mbutu E.M.N (2013). Factors Influencing Rabbit Farming. A case of rabbit production project in Abothuguchi west division, Meru county, Kenya. Department of Agricultural Economics, University of Nairobi, Kenya

Merck Veterinary Manual (2010). A handbook of Diagnosis and Therapy for Veterinarian. 10th edition. Merck and Co. Rahway, Ed. D.H.Siegmund.

Ogbonna, O. I. (2015). Roles of households in rabbit production in Enugu-North Agricultural zone of Enugu State. Journal of Agricultural Extension, 19(1). ISSN 24086851. http://dx.doi.org/10.4314.jae.v19i1.4 